\title{
Pengaruh Kepadatan Spat Kerang Mutiara (Pinctada maxima) dengan Metode Longline terhadap Pertumbuhan dan Kelangsungan Hidup
}

\author{
Zaenal Ahmad ', Muhammad Junaidi", Baiq Hilda Astriana ${ }^{3}$ \\ 1,2,3Program Studi Budidaya Perairan, Jurusan Perikanan dan Ilmu Kelautan, Fakultas Pertanian, Universitas Mataram. \\ Jln. Pendidikan No. 37 Mataram, Indonesia
}

Riwayat artikel

Received : 8 Juli 2019

Revised : 27 September 2019

Accepted : 8 Oktober 2019

Published : 22 Oktober 2019

*Corresponding Author: Muhammad Junaidi, Jurusan Perikanan dan Ilmu Kelautan Fakultas Pertanian, Universitas Mataram, Jl. Pendidikan No. 37 Mataram. Email: m.junaidi@unram.ac.id

\begin{abstract}
Abstrak : Penelitian kepadatan spat kerang mutiara yang dipelihara di alam perlu terus dilakukan karena belum ada patokan tingkat kepadatan yang sesuai untuk usaha komersial. Oleh karena itu dilakukan penelitian dengan tujuan mengetahui pengaruh kepadatan terhadap pertumbuhan dan tingkat kelangsungan hidup spat kerang mutiara (Pinctada maxima). Metode yang digunakan adalah Rancangan Acak Kelompok (RAK) terdiri dari 5 perlakuan dan 3 ulangan, yakni perlakuan A (60 ind/poket), B (75 ind/poket), C (90 ind/poket), D (105 ind/poket), dan perlakuan E (120 ind/poket). Ukuran spat yang digunakan rata-rata $1 \mathrm{~cm}$ pada poket (keranjang pemeliharaan) $45 \times 60$ $\mathrm{cm}^{2}$. Hasil penelitian selama 45 hari menunjukan bahwa pertumbuhan pada semua perlakuan tidak berbeda nyata, namun pertumbuhan terbaik dengan nilai $0,70 \mathrm{~cm}$ untuk pertumbuhan mutlak dan $0,69 \%$ untuk laju pertumbuhan harian dimiliki oleh kepadatan yang rendah yakni 60 ind/poket, disusul oleh perlakuan lainnya seperti perlakuan B,C,D, dan E. Hasil uji ANOVA, SR didapatkan hasil persentase yang berbeda nyata, yakni terdapat pada perlakuan A (60 ind/poket) dengan nilai SR 90,44\% dan pada perlakuan E (120 ind/poket) dengan nilai SR $74,44 \%$. Berdasarkan hasil penelitian, disimpulkan bahwa padat penebaran yang berbeda tidak berpengaruh nyata terhadap pertumbuhan spat kerang mutiara, namun berpengaruh nyata terhadap tingkat kelangsungan hidup (SR) spat kerang mutiara (Pinctada maxima) yang dipelihara selama 45 hari.
\end{abstract}

Kata kunci : Pertumbuhan, kelangsungan hidup, spat, Pinctada maxima

Abstract : The study of pearl shell spat density maintained in nature needs to be continued because there is no standard level of density suitable for commercial businesses. Therefore a study was conducted with the aim of knowing the effect of density on growth and survival rate of pearl oyster spat (Pinctada maxima). The method used is Randomized Block Design (RBD) consisting of 5 treatments and 3 replications, namely treatment A (60 ind / pocket), B (75 ind / pocket), C (90 ind / pocket), D (105 ind / pocket) ), and treatment $\mathrm{E}$ (120 ind / pocket). The size of the spat used was $1 \mathrm{~cm}$ on the pocket (maintenance basket) $45 \times 60 \mathrm{~cm}^{2}$. The results of the 45 -day study showed that growth in all treatments was not significantly different, but the best growth was $0.70 \mathrm{~cm}$ for absolute growth and $0.69 \%$ for the daily growth rate owned by a low density of 60 ind / pocket, followed by treatment others such as treatment $\mathrm{B}, \mathrm{C}, \mathrm{D}$, and E. The results of the SR ANOVA test showed that the percentage results were significantly different, which were found in treatment A (60 ind / pocket) with SR values of $90.44 \%$ and in treatment E (120 ind / pocket) with an SR of $74.44 \%$. Based on the results of the study, it was concluded that the different stocking densities had no significant effect on the growth of pearl shell spat, but significantly affected the survival rate (SR) of pearl shell spat (Pinctada maxima) which was maintained for 45 days.

Keywords: growth, survival rate, spat, Pinctada maxima. 


\section{Pendahuluan}

Kerang mutiara, Pinctada maxima adalah salah satu jenis kekerangan dari kelas bivalvia, biota ini memiliki potensi yang sangat besar karena hampir semua bagian dari tubuhnya mempunyai nilai jual, baik mutiara, cangkang, daging dan organisme kerang itu sendiri (benih maupun induk) (Taufik et al., 2007). Butiran permata yang dihasilkan oleh kerang ini merupakan komoditas ekspor yang penting bagi Indonesia karena memiliki nilai jual yang tinggi dan juga sebagai penyumbang devisa cukup besar bagi negara (Sinaga, Hartoko and Wisnu, 2015). Nilai ekspor kooditas ini pada tahun 2016 mencapai nilai 45.293 ribu US\$. Produk ini diekspor ke 9 negara, yang terbesar yaitu ke Negara Hongkong, Australia, Jepang dan China (Kristiningrum and Bendjamin, 2018). Jenis-jenis kerang mutiara yang ada di Indonesia adalah Pinctada maxima, $P$. margaritifera, $P$. chimnitzii, $P$. fucata dan Pteria penguin. Dari kelima spesies tersebut yang dikenal sebagai penghasil mutiara terpenting yaitu $\mathrm{P}$. maxima, $P$. margaritifera dan Pteria penguin (Taufik et al., 2007).

Provinsi Nusa Tenggara Barat (NTB) merupakan salah satu daerah pengembangan budidaya mutiara di Indonesia, karena kondisi perairan yang mendukung sehingga kualitas mutiara di Privinsi NTB dikenal sebagai mutiara yang terbaik di dunia (Habib et al., 2018; Oktaviani, Cokrowati and Astriana, 2018). Kerang mutiara dapat hidup di perairan pada kisaran salinitas antara 24 ppt dan 50 ppt, sedangkan kisaran ideal untuk peertumbuhan dan kelangsungan hidupnya adalah antara 32- 35 ppt (Kota, 2016). Suhu yang baik untuk kelangsungan hidup kerang mutiara berkisar antara 28-30 ${ }^{\circ} \mathrm{C}$, pada musim kemarau, dimana suhu air laut naik, kerang mutiara dapat tumbuh dengan maksimal (Taufik et al., 2007). Kecepatan arus pada perairan mempengaruhi laju filtrasi dari kerang mutiara. Kerang mutiara memiliki sifat filter feeder, sehingga sangat membutuhkan peranan arus perairan yang membawa plankton sebagai makanan alami bagi kerang mutiara, dimana kecepatan arus yang dapat mendukung pertumbuhan kerang mutiara yaitu antara $0.1-0 . .3 \mathrm{~m} / \mathrm{s}$ dan daerah yang memiliki kecepatan arus $>0.4 \mathrm{~m} / \mathrm{s}$ sebaiknya dihindari (Taufik et al., 2007).

Salah satu tahapan penting dalam kegiatan budidaya kerang mutiara adalah kegiatan pendederan. Pendederan spat kerang mutiara umumnya dipindahkan dari hathery ke tempat pendederan di laut pada saat mencapai ukuran panjang engsel sekitar 3-5 mm (Winanto et al, 2016). Kecilnya kelangsungan hidup (survival rate) pada tahapan pendederan ini diduga karena adanya masa transisi dari pemeliharaan di hatchery ke ke laut. Dengan demikian, selama pendederan, spat memerlukan penanganan dan perawatan yang optimal sehingga pertumbuhan dan survival rate tinggi. Salah satu upaya penanganan dan perawatan spat yang sangat menentukan keberhasilhan pendederan adalah kepadatan spat dalam keranjang pemeliharaan (poket). Seiring dengan meningkatnya ukuran spat maka akan terjadi kompetisi terhadap ruang atau tempat pemeliharaan dan makanan/pakan. Bahkan ditemukan spat saling menempel sehingga perlunya dilakukan kegiatan penjarangan. Dengan penjarangan ini diharapkan pertumbuhan spat menjadi normal dan tingkat kelangsungan hidup menjadi tinggi (Kotta, 2017).

Dalam satu siklus pendederan membutuhkan waktu selama 10 bulan dengan ukuran spat mencapai 6-8 $\mathrm{cm}$ dengan laju pertumbuhan rata-rata $0,7 \mathrm{~cm}$ per bulan dengan survival rate sekitar 5-10\% (Kotta, 2017). Padat penebaran yang umumnya digunakan dalam pemeliharaan anakan spat kerang mutiara dalam keranjang (poket) yaitu 50-60 ekor untuk ukuran 3-5 cm (Winanto, 2004). Untuk ukuran spat $0,8-1 \mathrm{~cm}$ kepadatan yang dianjurkan berkisar antara $93-225$ ekor per poket (Oktaviani, Cokrowati and Astriana, 2018). Penelitian kepadatan spat kerang mutiara yang dipelihara di alam perlu terus dilakukan karena belum ada patokan tingkat kepadatan yang sesuai untuk usaha komersial. Oleh karena itu dilakukan penelitian dengan tujuan mengetahui pengaruh kepadatan terhadap pertumbuhan dan tingkat kelangsungan hidup spat kerang mutiara (Pinctada maxima).

\section{Bahan dan Metode}

\section{Lokasi Penelitian}

Penelitian dilaksanakan pada bulan Juni sampai dengan Agustus 2018 di Perairan Pulau Kaung Kecamatan Buer Kabupaten Sumbawa, Nusa Tenggara Barat (Gambar 1).

\section{Bahan dan Alat}

Alat yang digunakan pada penelitian ini antara rakit apung, poket, tali PE, mesin pembersih, speed boat, waring, baskom kecil, longline, alat ukur kualitas air seperti pH, salinitas, suhu, kecerahan, kedalaman, kecepatan arus, plankton net. Hewan uji yang digunakan yaitu spat kerang mutiara ukuran dorsal ventral $1 \pm 0.2 \mathrm{~cm}$ (Gambar 2).

\section{Metode Penelitian}

Penelitian ini menggunakan metode eksperimen, yang disusun dengan rancangan acak kelompok (RAK), dengan perlakuan kepadatan (individu/poket). Kepadatan sebagai faktor perlakuan yang digunakan sebanyak lima level diantaranya yaitu perlakuan $\mathrm{A}=60$ individu/poket, $\mathrm{B}=75$ individu/poket, $\mathrm{C}=90$ individu/poket, $\mathrm{D}=105$ individu/poket, $\mathrm{E}=120$ individu/poket. Tata letak unit penelitian dan skema penempatan poket dan long line 
dapat dilihat pada Gambar 3.

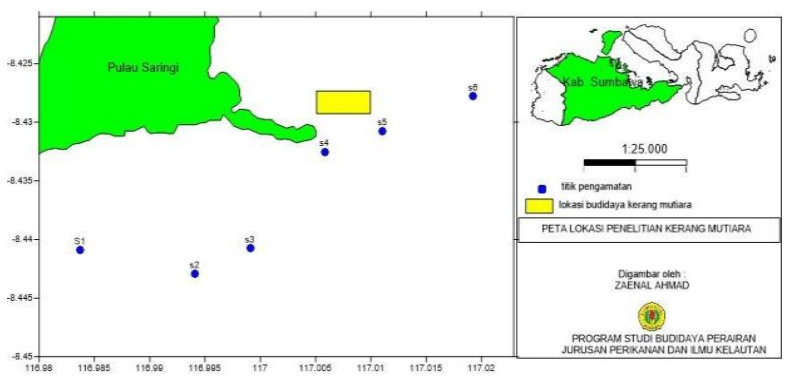

Gambar 1. Lokasi penelitian

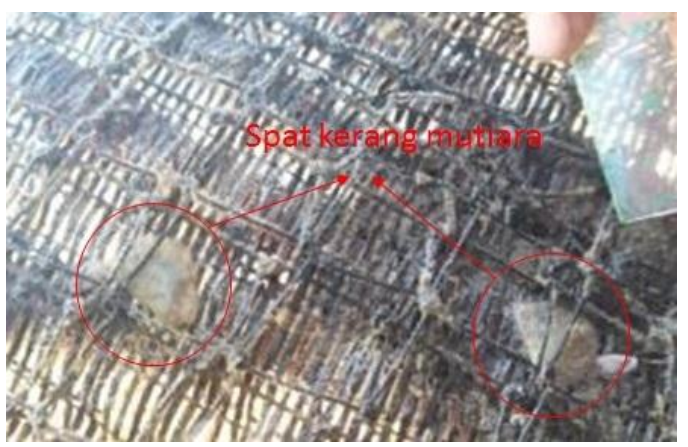

Gambar 2. Spat kerang mutiara

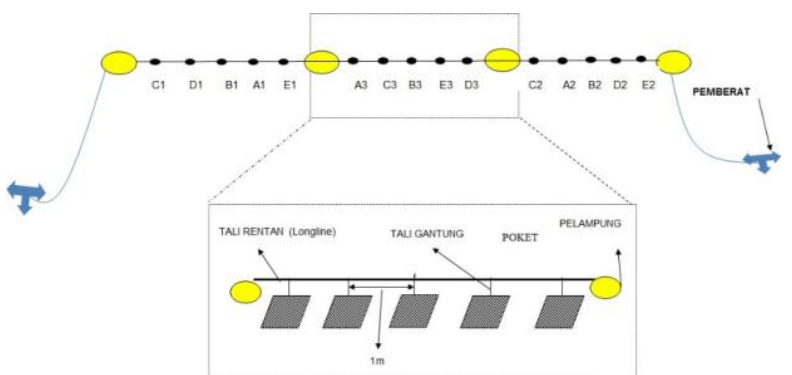

Keterangan : Keranjang pemeliharaan (poket) ada 5 perlakuan dan 3 ulangan dengan kepadatan yang berbeda pada masingmasing perlakuan, yaitu: Perlakuan A 60 ind/poket, B (75 ind/poket, C (90 ind/poket), D (105 ind/poket), E (120 ind/poket).

Gambar 3. Tata letak unit penelitian

\section{Pengamatan dan Analisis Data}

Parameter diukur antara lain pertumbuhan mutlak (PM), laju pertumbuhan harian (LPH), tingkat kelangsungan hidup (TKH) dan kualitas air yang meliputi suhu perairan, $\mathrm{pH}$, salinitas, kecerahan, kedalaman, kecepatan arus, kadar fosfat dan kelimpahan plankton. Pertumbuhan mutlak dilakukan terhadap panjang antero-posterior (Taylor et al., 1997). Laju pertumbuhan harian dihitung menurut (Deng et al., 2013). Pengamatan terhadap kualitas air di lokasi percobaan dilakukan sebagai data pendukung pada percobaan. Parameter kualitas air yang diamati, teknik pengambilan sampel dan prosedur pengamatannya sama seperti pada percobaan sebelumnya. Data yang diperoleh dianalisis dengan uji F. Jika uji F menunjukkan adanya pengaruh nyata $(\mathrm{P}<0,05)$ pada tiap perlakuan, maka dilanjutkan analisis dengan uji rerata Tukey. Pengolahan data dilakukan dengan menggunakan software SPSS versi 15 for Window.

\section{Hasil dan Pembahasan}

\section{Hasil Analisis Data}

Berdasarkan analisis sidik ragam data hasil penelitian dan pengamatan spat kerang mutiara (Pinctada maxima) menunjukan bahwa padat tebar yang berbeda memberikan pengaruh yang berbeda nyata $(\mathrm{p}<0,05 \%)$ terhadap tingkat kelangsungan hidup, namun untuk pertumbuhan panjang mutlak serta laju pertumbuhan panjang harian menunjukan tidak adanya perbedaan yang nyata $(\mathrm{p}>0,05)($ Tabel 1$)$.

Tabel 1. Hasil analisis data pertumbuhan panjang mutlak, laju pertumbuhan panjang harian dan tingkat kelangsungan hidup (SR) spat kerang mutiara (Pinctada maxima)

\begin{tabular}{lccccc}
\hline \multirow{2}{*}{ Parameter } & \multicolumn{5}{c}{ Perlakuan (kepadatan = ind/poket) } \\
\cline { 2 - 6 } & $\mathrm{A}(60)$ & $\mathrm{B}(75)$ & $\mathrm{C}(90)$ & $\mathrm{D}(105)$ & $\mathrm{E}(120)$ \\
\hline $\mathrm{PM}(\mathrm{cm})^{\mathrm{ns}}$ & $0.70 \pm 0.40$ & $0.65 \pm 0.37$ & $0.57 \pm 0.33$ & $0.54 \pm 0.31$ & $0.44 \pm 0.25$ \\
LPH (\%) & $0.02 \pm 0.40$ & $0.01 \pm 0.37$ & $0.01 \pm 0.33$ & $0.01 \pm 0.31$ & $0.01 \pm 0.25$ \\
TKH $(\%)^{\mathrm{s}}$ & $90.4 \pm 6.2^{\mathrm{b}}$ & $87.9 \pm 1.3^{\text {ab }}$ & $85.9 \pm 7.1^{\mathrm{ab}}$ & $80.6 \pm 5.6^{\mathrm{ab}}$ & $7444 \pm 4.7^{\mathrm{a}}$ \\
\hline
\end{tabular}

Keterangan : Huruf yang berbeda notasi menunjukan hasil yang berbeda nyata signifikan); ns : tidak berbeda nyata; s : berbeda nyata

\section{Pertumbuhan Mutlak}

Rerata pertumbuhan panjang cangkang spat kerang mutiara pada kepadatan 60 ind/poket (Perlakuan A) cenderung lebih cepat dengan hasil nilai tertinggi sebesar 0,703 cm dibandingkan dengan kepadatan lainnya perlakuan $\mathrm{B}(0,65) \mathrm{cm}$, perlakuan $\mathrm{C}(0,566) \mathrm{cm}$, perlakuan D $(0,54) \mathrm{cm}$ dan perlakuan $\mathrm{E}(0,44) \mathrm{cm}$. Hasil pertumbuhan panjang mutlak spat kerang mutiara (Pinctada maxima) dapat dilihat pada Gambar 4. 


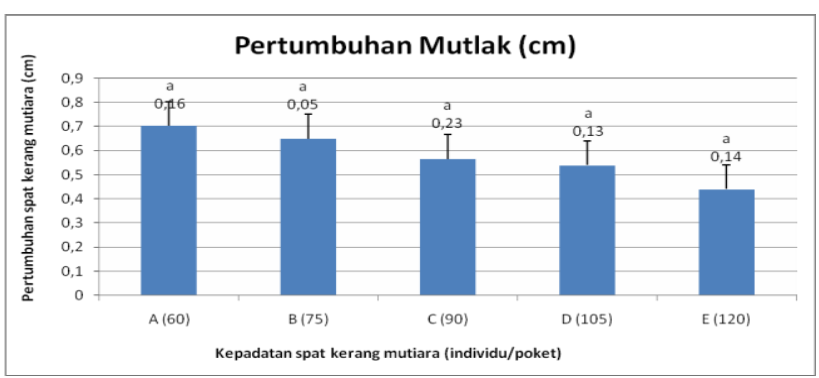

Gambar 4. Grafik pertumbuhan panjang mutlak spat kerang mutiara (Pinctada maxima).

Berdasarkan analisis sidik ragam diperoleh pertumbuhan mutlat tidak berbeda nyata (non signifikan) pada setiap perlakuan, diduga disebabkan karena pengamatan pertumbuhan panjang mutlak yang dilakukan selama 45 hari belum cukup untuk melihat pertumbuhan spat yang signifikan. Jika ditinjau dari faktor fisiologisnya. menurut (Rosanawita et al., 2017), kerang termasuk ke dalam filum moluska yang pertumbuhannya relatif lama bahkan untuk mencapai ukuran $12 \mathrm{~cm}$ bisa membutuhkan waktu selama 6 bulan - 12 bulan. Oleh karena itu. masa pemeliharaan 45 hari bukan merupakan jangka waktu yang sesuai untuk melakukan pengamatan terhadap pengukuran pertumbuhan. Padahal dalam usaha budidaya pertumbuhan panjang yang menjadi acuan untuk harga jual. Spat yang berkelompok dan saling menempel menyebabkan pertumbuhan salah satunya akan terhambat (Winanto, 2004). Ditambahakan oleh (Taufik et al., 2007), pertumbuhan kerang dipengaruhi oleh adanya kompetisi memperoleh ruang dan makanan. Peluang untuk mendapatkan makanan lebih besar terjadi pada spat yang tidak bergerombol dan saling menindih. Pertumbuhan kerang mutiara dipengaruhi juga oleh kompetisi intraspesifik terhadap pakan yaitu biofouling (organisme penempel) (Sudewi et al., 2010). Biofouling menutupi waring pemeliharaan dan cangkang mutiara akibatnya kerang mutiara terhambat dalam mendapatkan makanan.

\section{Laju Pertumbuhan Harian}

Laju pertumbuhan harian rerata panjang cangkang spat kerang mutiara pada kepadatan 60 ind/poket (Perlakuan A) cenderung lebih cepat dengan nilai rerata $0.69 \%$ dibandingkan dengan kepadatan lainnya perlakuan B $(0,62 \%)$, perlakuan $\mathrm{C}(0,51 \%)$, perlakuan $\mathrm{D}(0,46 \%)$ dan perlakuan $\mathrm{E}(0,35 \%)$. Hasil laju pertumbuhan harian spat kerang mutiara (Pinctada maxima) dapat dilihat pada Gambar 5.

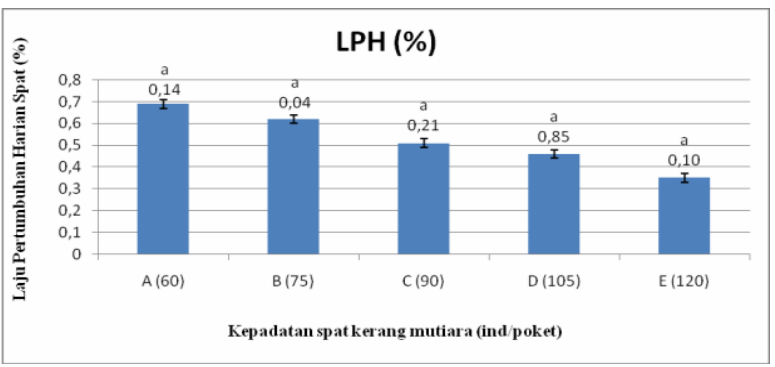

Gambar 5. Grafik pertumbuhan harian spat kerang mutiara (Pinctada maxima).

Laju pertumbuhan harian rerata panjang cangkang spat kerang mutiara yang telah diperoleh dari hasil penelitian(Gambar 5) tersebut relatif lebih tinggi jika dibandingkan dengan hasil penelitian yang didapat oleh (Taufik et al., 2007) di perairan Teluk Sopenihi. Pulau Sumbawa yakni capaian nilai laju pertumbuhan hariannya adalah $0.29 \%$ per hari. Hal ini sesuai dengan pendapat (Dody, 2017), bahwa pemeliharaan anakan kerang mutiara sebaiknya dalam keranjang pemeliharaan agar dapat memberikan hasil pertumbuhan yang baik serta kerang bebas mendapatkan pasokan makanan dari lingkungan perairan sekitar. Adapun faktor lain yang dapat mempengaruhi pertumbuhan spat kerang mutiara yakni faktor dari luar seperti lingkungan perairan dan dari faktor dalam spat kerang mutiara yakni faktor genetik. Kecenderungan monomorfik pada turunan pertama (F1) mengindikasikan hilangnya alel-alel penting seperti alel yang dibutuhkan dalam toleransi suhu (Wardana et al., 2014). Fungsi biomineralisasi termasuk pembentukan cangkang. fungsi pertumbuhan dan alel yang diperlukan untuk adaptasi terhadap perubahan lingkungan perairan yang diakibatkan oleh adanya variasi musim. Sedangkan Koehn et al.. (1984) dalam Wardana et al.(2014a) menjelaskan bahwa tinggi rendahnya variasi genetik pada suatu populasi sangat dipengaruhi oleh letak geografis. perbedaan salinitas dan suhu.

\section{Tingkat Kelangsungan Hidup}

Tingkat kelangsungan hidup spat kerang mutiara (Pinctada maxima) tertinggi pada perlakuan A (60 ind/poket) yaitu sebesar $90,55 \%$, selanjutnya perlakuan B (75 ind/poket) yaitu sebesar $88 \%$, perlakuan C (90 ind/poket) yaitu sebesar $85,92 \%$, perlakuan D (105 ind/poket) sebesar $80,63 \%$ dan terendah pada perlakuan $\mathrm{E}$ (120 ind/poket) yaitu sebesar 74,44\%. Grafik tingkat kelangsungan hidup (SR) dapat dilihat pada Gambar 6. 


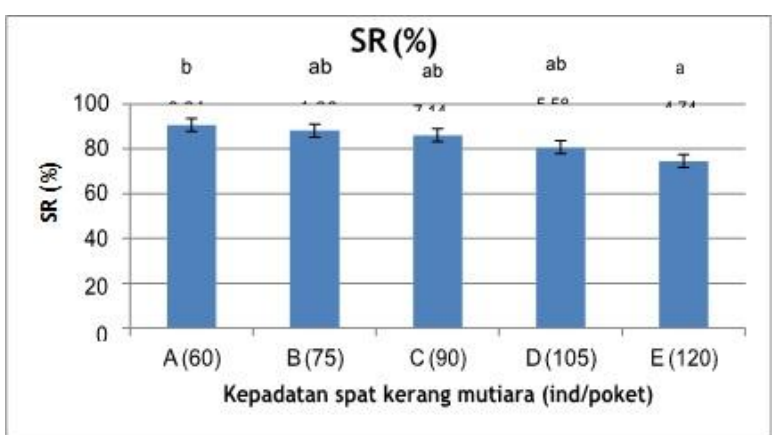

Gambar 6. Grafik tingkat kelangsungan hidup spat kerang mutiara (Pinctada maxima).

Pada Gambar 6 diketahui bahwa survival rate (SR) sebesar $74-90 \%$ dengan rerata $83.90 \%$. Hasil survival yang dicapai tergolong baik. Tomatala (2014) menyatakan bahwa persentase SR pada kerang mutiara mencapai $90 \%$ dapat dikatakan SR yang tergolong maksimal. SR cukup baik berkisar dari 45-65\%, sedangkan SR yang termasuk dalam ketegori rendah adalah kurang dari 10\% (Wardana et al., 2014a; Wardana et al., 2014b; Wardana et al., 2015). Winanto, 2004 menyatakan bahwa masa transisi yang cukup kritis dalam kehidupan spat terjadi setelah spat dipindahkan ke tempat pemeliharaan di laut dan bila tidak ditangani dengan baik menyebabkan kematian (mortalitas) mencapai $98 \%$. Tingginya persentase SR diasumsikan terjadi karena spat melekat dengan baik pada wadah pemeliharaan (poket) sehingga pada saat poket diikat dan digantung secara horisontal di dalam kolom perairan tidak ditemukan adanya spat yang terjatuh pada dasar kantong waring. Spat yang terdapat pada dasar kantong waring berpotensi besar mengalami kematian karena persaingan memperoleh makanan dan ruang dengan poket pada saat adanya gelombang.

Jika SR rendah atau sangat rendah pada pendederan spat kerang mutiara salah satunya disebabkan karena frekuensi pergantian waring yang jarang dilakukan. Menurut Winanto et al. (2016) jika selama pemeliharaan terjadi keterlambatan dalam pergantian cover net, maka mata jaring akan tertutup oleh kotoran dan organisme penempel. sehingga sirkulasi air terhambat. Akibatnya. pasokan makanan dan oksigen terlarut dari perairan juga menjadi terhambat. sehingga berpengaruh terhadap laju pertumbuhan dan tingkat kelangsungan hidup.

\section{Kualitas Perairan}

Pengukuran kualitas air dilakukan setiap tiga minggu sekali selama masa pemeliharaan. Parameter yang diukur adalah suhu $\left({ }^{\circ} \mathrm{C}\right)$, salinitas (ppt), kecepatan arus $(\mathrm{cm} / \mathrm{dt})$, kedalaman $(\mathrm{m})$, kecerahan $(\mathrm{m})$, dan $\mathrm{pH}$.
Hasil pengukuran parameter kualitas air spat kerang mutiara (Pinctada maxima) yang dilakukan 1 bulan sekali dapat dilihat pada Tabel 2.

Jenis Plankton yang ditemukan terdiri dari 19 spesies, meliputi kelas Bacillariophyceae (10 spesies), kelas Dinophyceae (5 spesies),Coscinodiscophyceae (1 spesies) dan Pavlovophyceae (1 spesies). Plankton yang ditemukan semuanyaadalah jenis fitoplankton. Fitoplankton dari kelas Bacillariophyceae (Diatom) merupakan spesies yang paling banyak ditemukan. (Anwar et al., 2004) menyatakan bahwa komposisi fitoplankton di laut didominasi oleh kelompok Bacillariophyceae dan Dinophyceae sedangkan kelompok Coscinodiscophyceae dan Pavlovophyceae ada tapi sangat sedikit. Persentase jumlah spesies fitoplankton di perairan sekitar lokasi pemeliharaan dapat dilihat pada Gambar 7.

Tabel.2 Hasil pengukuran kualitas air spat kerang mutiara (Pinctada maxima)

\begin{tabular}{|c|c|c|c|c|}
\hline Parameter & Kisaran & Rerata & Kelayakan & Rujukan \\
\hline Suhu $\left({ }^{\circ} \mathrm{C}\right)$ & $28-32$ & 30.11 & $27-31$ & (Kotta, 2017) \\
\hline $\mathrm{pH}$ & $6.3-7.6$ & 6.90 & $6-8$ & $\begin{array}{l}\text { (Rosanawita, } \\
\text { Dewiyanti } \\
\text { and } \\
\text { Octavina, } \\
\text { 2017) }\end{array}$ \\
\hline $\begin{array}{l}\text { Salinitas } \\
(\% \text { ) }\end{array}$ & $26-35$ & 31.38 & $24-36$ & $\begin{array}{l}\text { (Hamzah and } \\
\text { Nababan, } \\
\text { 2009) }\end{array}$ \\
\hline Kecerahan (m) & $6.5-8.0$ & 7.42 & $4.5-6.5$ & $\begin{array}{l}\text { (Sutaman, } \\
\text { 1993) }\end{array}$ \\
\hline $\begin{array}{l}\text { Kedalaman } \\
\text { (m) }\end{array}$ & $12-16$ & 13.83 & $12-18$ & $\begin{array}{l}\text { (Winanto, } \\
\text { 2004) }\end{array}$ \\
\hline $\begin{array}{l}\text { Kecepatan } \\
\text { arus } \\
(\mathrm{cm} / \mathrm{dt})\end{array}$ & $\begin{array}{l}5.45- \\
17.24\end{array}$ & 10.72 & $5-12.7$ & $\begin{array}{l}\text { (Jamilah, } \\
\text { 2015) }\end{array}$ \\
\hline $\begin{array}{l}\text { Fosfat } \\
(\mathrm{mg} / \mathrm{L})\end{array}$ & $0.8-1.2$ & 1.01 & $0.09-1.80$ & $\begin{array}{l}\text { (Jamilah, } \\
\text { 2015) }\end{array}$ \\
\hline
\end{tabular}

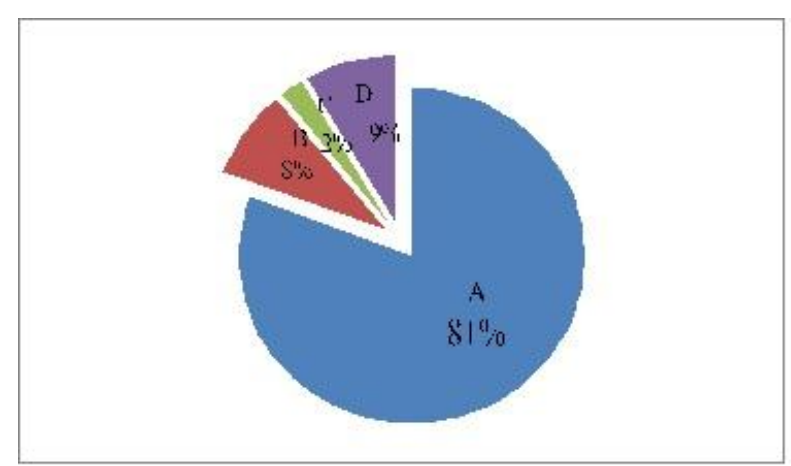

Gambar 7. Komposisi jumlah jenis fitoplankton berdasarkan kelas (A : Bacillariophyceae; B: Dinophyceae; C : Coscinodiscohyceae; D: Pavlovophyceae) 
Keadaan lingkungan juga dapat berpengaruh terhadap kerang mutiara. Pada Tabel 2 di atas terlihat bahwa suhu perairan dilokasi adalah $28-32{ }^{\circ} \mathrm{C}$ dengan rata-rata $30.11^{\circ} \mathrm{C}$. Menurut Winanto (2004), kerang mutiara dapat hidup dan berkembangbiak dengan baik pada lingkungan perairan yang memiliki suhu $27-31{ }^{\circ} \mathrm{C}$, sedangkan menurut Tomatala (2014), spat kerang mutiara Pinctada maxima dapat hidup pada perairan dengan suhu 26.4-30 ${ }^{\circ} \mathrm{C}$. Dengan demikian kondisi perairan masih dalam kisaran ambang toleransi bagi kehidupan kerang mutiara.

Hasil pengukuran dilapangan terhadap nilai $\mathrm{pH}$ diperoleh nilai $\mathrm{pH}$ berkisar antar 6.3-7.6, kondisi masih dalam batas standar baku mutu menurut Peraturan Gubernur Bali No.8 Tahun 2007 dan Keputusan Menteri Lingkungan Hidup Nomor 51 Tahun 2004 bahwa standar baku mutu air laut untuk biota laut untuk $\mathrm{pH}$ adalah 78.5. Hal ini sesuai juga dengan pendapat Rosanawita et al (2017) bahwa pH air laut umumnya berada pada kisaran 6-8. Derajat keasaman air yang layak untuk kehidupan kerang mutiara $P$. maxima berkisar 7.8-8.6 dan dapat berkembang baik pada kisaran 7.9-8.2 (Winanto, 2004).

Salinitas merupakan salah faktor penting dalam kegiatan budidaya kerang mutiara dan bivalvia jenis ini lebih menyukai perairan yang bersalinitas tinggi. Hamzah (2015) mengemukakan bahwa kisaran kualitas air yang masih layak untuk pemeliharaan kerang mutiara yaitu salinitas anatara 24-36 ppt. Sedangkan hasil pengukuran salinitas dilapangan adalah 28-35 ppt dengan rata-rata yaitu 31.38 ppt. Dengan demikian salinitas dilapangan masih dalam kondisi yang layak untuk spat kerang mutiara. Hasil pengukuran kecerahan pada lokasi penelitian menunjukan nilai yang baik yaitu 6.5-8 meter. Menurut Sutaman (1993) untuk keperluan budidaya kerang mutiara selayaknya dipilih lokasi yang mempunyai kecerahan antara 4.5-6.5 meter. Hal ini berarti tingkat kecerahan pada lokasi pemeliharaaan masih tergolong layak. Kedalaman perairan di lokasi budidaya mempunyai pengaruh yang cukup besar terhadap kualitas mutiara. Berdasarkan penelitian Sutaman (1993) semakin dalam letak kerang mutiara yang dipelihara. maka kualitas mutiara yang dihasilkan akan semakin baik, dimana edalaman yang dimaksud yaitu 12-18 meter. Kedalaman tersebut cocok untuk budidaya kerang mutiara dikarenakan pada kedalaman ini pertumbuhan kerang mutiara jga akan lebih baik. Hasil pengukuran pada saat pemeliharaan didapatkan kisaran kedalaman yaitu 12-16 meter dengan rata-rata 13.83 meter. Dengan demikian kedalaman pada lokasi pemeliharaan masih tergolong ambang batas toleransi. Spat kerang mutiara yang dipelihara yaitu pada kedalaman 13 meter.
Hasil penelitian dilapangan diperoleh kecepatan arus yang cukup normal yaitu berkisar 5.45-17.24 cm/dt. Kecepatan arus pada perairan mempengaruhi laju filtrasi dari kerang mutiara. Kerang mutiara memiliki sifat filter feeder, sehingga sangat membutuhkan peranan arus perairan yang membawa plankton sebagai makanan alami bagi kerang mutiara. Kecepatan arus terkait dengan distribusi oksigen dan makanan alami seperti fitoplankton dalam badan air serta penempelan biofouling dan kerusakan pada instalasi budidaya kerang mutiara. Kecepatan arus yang layak untuk budidaya kerang mutiara adalah yaitu 5- $12.7 \mathrm{~cm} / \mathrm{dt}$ (Jamilah, 2015). Kandungan fospat perairan di lokasi didapatkan antara 0.8-1.2 mg/L. yang merupakan kisaran untuk pertumbuhan fitoplankton. Hal tersebut sesuai dengan pernyataan Wardoyo (1974) dalam Jamila (2015) bahwa kandungan fospat yang optimum untuk pertumbuhan fitoplankton berkisar antara $0.09-1.80 \mathrm{mg} / \mathrm{L}$. Dengan demikian berdasarkan kadar phosphat-nya maka sebagian besar perairan di lokasi pemeliharaan masih berada pada kondisi yang optimum untuk pertumbuhan fitoplankton.

\section{Kesimpulan}

Berdasarkan analisis data hasil penelitian, diperoleh bahwa padat penebaran spat kerang mutiara yang dipelihara selama 45 hari dengan sistem longline berpengaruh nyata terhadap tingkat kelangsungan hidup, dan tidak berpengaruh nyata terhadap pertumbuhan mutlak dan laju pertumbuhan harian. Tingkat kelangsungan hidup yang terbaik diperoleh pada perlakuan kepadatan 60 ind/poket. Untuk memperoleh tingkat yang kelangsungan hidup yang memadai dalam budidaya spat kerang mutiara, sebaiknya digunakan kepadatan $60 \mathrm{ind} /$ poket.

\section{Ucapan Terima Kasih}

Ucapan terima kasih disampaikan kepada Handa Wiansyah, S.Pi. atas bantuan fasilitas yang digunakan selama penelitian di Pulau Kaung Kabupaten Sumbawa.

\section{Daftar Pustaka}

Anwar, K. et al. (2004) 'Food Habits of Pearl Oyster Pintada maxima in the Gulf of Sekotong , Lombok', J. Ilmu-Ilmu Periaran dan Perikanan Indonesia., 2(2), pp. 73-79.

Deng, Y. et al. (2013) 'Growth and Survival of Pearl Oyster Pinctada maxima Spat Reared under Different Environmental Conditions', Journal of Shellfish Research, 32(3), pp. 675-679. doi: 10.2983/035.032.0308. 
Dody, S. (2017) 'Uji coba penerapan teknologi budidaya kerang mutiara (Pinctada maxima) di Perairan Ternate Selatan, Maluku Utara', Prosiding Seminar Nasional KSP2K II, 1(2), pp. 167-173.

Habib, A. H. Al et al. (2018) 'Pemetaan Daerah Potensial Budidaya Tiram Mutiara (Pinctada Maxima) Menggunakan Citra Satelit Berdasarkan Parameter Hidrometeorologi Terhadap Pola Musiman Di Perairan Lombok, Nusa Tenggara', in Prosiding SNFA (Seminar Nasional Fisika dan Aplikasinya), pp. 1-13. doi: 10.20961/prosidingsnfa.v3i0.28500.

Hamzah, M. S. (2015) 'Pressure changes in media maintenance of shell pearl (Pinctada maxima) larvae on protease enzyme activity enhancing growth and survival', J. Ilmu dan Tek Kelautan Tropis, 7(2), pp. 655-670.

Hamzah, M. S. \& Nababan, B. (2009) 'The growth and survival study of pearl oyster seeds (Pinctada maxima) based on the difference depth levels in Kapontori Bay, Buton Island', 1(2), pp. 22-32.

Jamilah (2015) 'Analisis hidro-oseanografi untuk budidaya tiram mutiara di perairan Baubau', $J$. Biotek, 3(2), pp. 92-105.

Kota, R. (2016) 'Pengaruh Kedalaman Terhadap Kelangsungan Hidup (Survival Rate) Benih Tiram Mutiara (Pinctada maxima) Stadia Spat', Agrikan: Jurnal Agribisnis Perikanan, 9(1), pp. 30-38. doi: 10.29239/j.agrikan.9.1.30-38.

Kotta, R. (2017) 'Pertumbuhan dan perkembangan spat tiram mutiara (Pinctada maxima ) di Perairan Ternate Selatan Pulau Ternate', in Prosiding Seminar Nasional KSPK II, pp. 158-166.

Kristiningrum, E. \& Bendjamin, B. (2018) 'Standardization Support on Pearl Oyster Cultivation', J. Standarisasi, 20(2), pp. 147-158.

Oktaviani, T., Cokrowati, N. \& Astriana, B. H. (2018) 'The survival rate of pearl shell spat with differnet densities at the Marine Aquaculure Center Lombok', Jurnal Kelautan, 11(1), pp. 47-55. doi: 10.21107/jk.v11i1.3136.

Rosanawita, R., Dewiyanti, I. \& Octavina, C. (2017) 'Effect of Different Stocking Density on the
Growth and Survival Ratess of Oyster Spats (Crassostrea sp.)', Jurnal Ilmiah Mahasiswa Kelautan dan Perikanan Unsyiah, 2(1), pp. 213220.

Sinaga, S. G., Hartoko, A. \& Wisnu, R. (2015) 'Analysis of Seawater Suitability Pari Island Water as a Pearl Oyster (Pinctada maxima) Cultivation Using Remote Sensing and Geographic Information System Application', Journal of Aquaculture Management and Technology, 4(2), pp. 100-108.

Sudewi et al. (2010) 'Nursery of pearl oyster, Pinctada maxima at different depth', J. Fish. Sci., 12(2), pp. 57-63.

Sutaman (1993) Tiram Mutiara Teknik Budidaya dan Proses Pembuatan Mutiara. Yogyakarta: Kanisius.

Taufik, N. et al. (2007) 'Pertumbuhan Tiram Mutiara ( Pinctada maxima ) pada Kepadatan Berbeda', Ilmu Kelautan, 12(1), pp. 31-38.

Taylor, J. J., Rose, R. A. \& Southgate, P. C. (1997) 'Effects of stocking density on the growth and survival of juvenile silver-lip pearl oysters (Pinctada maxima, Jameson) in suspended and bottom culture', Journal of Shellfish Research, 16(2), pp. 569-572.

Tomatala, P. (2014) 'Effectiveness of using frame net in spacing process of pearl oyster seeds, Pinctada maxima', Budidaya Perairan, 2(1), pp. 1-6.

Wardana, I. K., Sudewi, \& Muzaki, A., et al. (2014) 'Profile of pearl oyster (Pinctada maxima) seeds resulted from controlled spawning', J. Oseanologi Indonesia, 1(1), pp. 6-11.

Wardana, I. K., Sudewi, \& Supii, A. I., et al. (2014) 'Seleksi benih tiram mutiara (Pinctada maxima) dari hasil pemijahan induk alam dengan karakter nacre putih', Jurnal Riset Akuakultur, 9(1), p. 1. doi: 10.15578/jra.9.1.2014.1-13.

Wardana, I. K. et al. (2015) 'Performa benih tiram mutiara (Pinctada maxima) dari hasil persilangan induk alam', Jurnal Riset Akuakultur, 10(3), pp. 357369. doi: 10.15578/jra.10.3.2015.357-369. 
Junaidi, M. et al., Jurnal Biologi Tropis, 19 (2) : $221-228$

DOI: $10.29303 /$ jbt.v19i2.1273

Winanto, T. (2004) Memproduksi benih tiram mutiara. Jakarta: Penebar Swadaya.

Winanto, T., Marasabessy, M. D. \& Dody, S. (2016) 'Kepadatan Optimum dan Morfologi Spat Tiram Mutiara Pinctada maxima (Jameson) pada Pemeliharaan dengan Tingkat Kepadatan Berbeda', OMNI Akuatika, 12(3), pp. 138-143. 